\title{
Effects of the toxic haptophyte Prymnesium parvum on the survival and feeding of a ciliate: the influence of different nutrient conditions
}

\author{
Edna Granéli*, Niclas Johansson \\ Department of Marine Sciences, University of Kalmar, Box 905, 39129 Kalmar, Sweden
}

\begin{abstract}
We studied the growth and feeding response of the ciliate Euplotes affinis when exposed to algal cultures of Prymnesium parvum and Rhodomonas cf. baltica as monocultures or as mixtures. Cultures of $P$. parvum grown under nutrient-limited ( $\mathrm{N}$ or $\mathrm{P}$ ) or nutrient-sufficient conditions were tested for toxicity against E. affinis. Ciliates grew well when fed $R$. cf. baltica, but avoided grazing on monocultures of $P$. parvum, regardless of algal concentration. Increasing abundances of $P$. parvum decreased survival of the ciliate, even if supplied as a mixture together with high concentrations of $R$. cf. baltica as an alternative prey. This implies that $P$. parvum produces substances that were fatal to the ciliate when released to the medium. The lethal effect of $P$. parvum was dependent on the physiological status of the cells, with the highest toxicity in nutrient-stressed cultures. Our results suggest that toxin production in P. parvum may be a chemical defense to repel predators.
\end{abstract}

KEY WORDS: Prymnesium parvum • Toxic algae $\cdot$ Grazing avoidance $\cdot$ Nutrient limitation $\cdot$ Grazing • Growth $\cdot$ Ciliate

Resale or republication not permitted without written consent of the publisher

\section{INTRODUCTION}

Toxic incidents of the haptophyte Prymnesium parvum have been known since the end of the last century (Strodtmann 1898). Since then, toxic blooms have been reported from brackish water localities in Europe, the Middle East, Ukraine, China and the USA (Moestrup 1994, Edvardsen \& Paasche 1998). These blooms have strongly affected coastal marine ecosystems and caused economic problems for commercial aquaculture. Therefore, it is important to understand the selective forces leading to bloom formation of this species. The ability of a specific phytoplankton species to become dominant and form blooms in natural environments is, apart from its competitive ability, also dependent on mortality losses. Grazing by herbivorous zooplankton is considered a major loss factor for the development of phytoplankton blooms (Watras et al. 1985, Uye 1986). Adaptations of algae to escape grazing would therefore directly favour the ecological success of that particular species. Several studies have shown that a number of phytoplankton species have the ability to produce toxic substances that stun, kill or repel potential grazers (Ives 1985, 1987, Sykes \& Huntley 1987, Hansen 1989, 1995, De Mott \& Moxter 1991, De Mott et al. 1991, Carlsson et al. 1995, Kamiyama \& Arima 1997). Thus, one of the reasons for toxin production in phytoplankton may be to escape grazing.

Among haptophytes, several species produce toxic substances with negative effects on other marine organisms. The toxins have mainly been considered a problem for gill-breathing animals as they destroy the selective permeability of the gill tissue (Yariv \& Hestrin 1961). However, there is also evidence for toxic effects on potential grazers. For instance, moderate abundances of Prymnesium patelliferum have a strong negative effect on copepod feeding and reproduction (Nejstgaard et al. 1995, Nejstgaard \& Solberg 1996). Nielsen et al. (1990) reported a high mortality of microzooplankton and copepods during a bloom of Chrysochromulina polylepis in the Kattegatt in 1988. In addition, Carlsson et al. (1990) showed that the C. polylepis 
toxin was lethal to the ciliate Favella ehrenbergi. From these results, it is evident that several haptophyte species have the capacity to become toxic or unpalatable to both ciliates and copepods. However, although several physiological and ecological studies of $P$. parvum have been performed, there have, to our knowledge, been no previous studies on interactions between $P$. parvum and zooplankton. Prymnesium toxins have a generalised membrane action (e.g. to destroy the permeability of cell membranes) and thus may affect organisms ranging from protozoa to fish (Igarashi et al. 1998, Sasaki et al. 2001). A relevant question to ask, therefore, is whether the potential for toxin production provides $P$. parvum with a selective advantage as a chemical defence against grazing.

Previous studies have shown that limiting conditions of either nitrogen or phosphorus enhance the toxic effect of Prymnesium parvum (Shilo 1971, Meldahl et al. 1994, Johansson \& Granéli 1999), suggesting that toxin production is a defence mechanism used to improve the competitive ability of $P$. parvum under conditions of severe nutrient competition. In the present study we investigated the survival and feeding of the ciliate Euplotes affinis, when exposed to mixed cultures of $P$. parvum and Rhodomonas cf. baltica, which all coexist in natural phytoplankton communities (Thomsen 1992, Johansson 2002). Cultures of $P$. parvum were grown under nitrogen $(\mathrm{N})$ or phosphorus (P) deficient or nutrient-sufficient conditions in order to compare differences in the toxic response of the ciliates related to nutrient conditions of the algae.

\section{MATERIALS AND METHODS}

Experimental organisms. A toxic strain of the haptophyte Prymnesium parvum (CCMP 708, equivalent spherical diameter [ESD] 7 to $9 \mu \mathrm{m}$ ) and a strain of the non-toxic chryptophyte Rhodomonas cf. baltica (Kalmar Algal Collection [KAC] 30, 6 to 8 um ESD) were obtained from KAC. $R$. cf. baltica was selected as the control species since it is similar in size (thus the grazers will have an alternative food source of the same size range which is not toxic to them) to $P$. parvum. The ciliate Euplotes affinis ( 40 to $70 \mu \mathrm{M}$ ) was isolated from a surface water sample from Kalmar Bay (Baltic Sea), Sweden, in July 1999. Stock cultures of P. parvum and $R$. cf. baltica were grown in autoclaved aged coastal seawater $(7 \%$ ) with $\mathrm{f} / 10$ enrichment (Guillard \& Ryther 1962). Vitamins (B12, biotin and thiamine) were added following the method of Schöne \& Schöne (1982). Cultures of $E$. affinis were grown in autoclaved seawater $(7 \%)$ enriched with EDTA, in polystyrene culture bottles (50 ml, Nunclon), to which $R$. cf. baltica was added every second day (at concentrations of $10^{3}$ to $10^{4}$ cells $\mathrm{ml}^{-1}$ ). The ciliates were transferred to new media every week. All cultures were maintained at $20^{\circ} \mathrm{C}$ on a $16 \mathrm{~h}$ light:8 h dark cycle under an irradiance of $100 \mu \mathrm{mol}$ $\mathrm{m}^{-2} \mathrm{~s}^{-1}$ provided by $36 \mathrm{~W}$ cool-white fluorescent lamps.

Ingestion rates of Euplotes affinis. The ingestion rates of the ciliate $E$. affinis were determined at 8 concentrations ( 0.5 to $12.0 \times 10^{3}$ cells ml ${ }^{-1}$ ) of either Rhodomonas cf. baltica or Prymnesium parvum in monocultures, or in mixtures of the 2 species (Table 1). To obtain different experimental concentrations of the 2 algae, the cultures were diluted with autoclaved seawater (nutrient concentrations: $0.1 \mathrm{\mu M} \mathrm{PO}_{4}{ }^{3-}$ and $1.2 \mu \mathrm{M} \mathrm{NO}_{3}{ }^{-}$). The experiments were performed in multiwells (Falcon multiwell, 24-well). Using a micropipette, 4 ciliates (together with 10 to $20 \mu \mathrm{l}$ of medium) were added to each well, which were then filled with $2 \mathrm{ml}$ of algal suspension (3 replicates for each algal concentration). After $4 \mathrm{~h}$ of incubation, the ingestion rates were calculated from the disappearance of algal cells in the suspension following the method of Frost (1972). The algal numbers were, after preservation with Lugol's solution, counted initially and at the end of incubations using a flow cytometer (FACS Calibur, Becton Dickinson). Grazing experiments were carried out at low light intensity $(15 \mu \mathrm{mol}$ $\mathrm{m}^{-2} \mathrm{~s}^{-1}$ ) to ensure minimal growth of the prey during the experiments.

Growth of Euplotes affinis. The response of E. affinis to different mixtures of Prymnesium parvum and Rhodomonas cf. baltica was studied in multiwells (Falcon multiwell, 24-wells). E. affinis were incubated together with: (1) $R$. cf. baltica $\left(10^{3}\right.$ cells $\mathrm{ml}^{-1}$, monocultures), (2) $R$. cf. baltica $\left(10^{3}\right.$ cells ml $\left.{ }^{-1}\right)$ and various concentrations of $P$. parvum ( 2 to $32 \times 10^{3}$ cells ml $^{-1}$ ) in mixed cultures, and (3) with only autoclaved algal medium ( $\mathrm{f} / 10$ ) that served as a starvation control. In order to test differences in indirect growth response of E. affinis related to nutrient conditions of the water,

Table 1. Ingestion rate $( \pm \mathrm{SD})$ for the ciliate Euplotes affinis feeding on cells of Rhodomonas cf. baltica (R) in the presence of Prymnesium parvum (P). The negative values of the ingestion rate are an artefact due to better growth of $R$. cf. baltica in the presence of $E$. affinis than in the controls where $R$. cf.

baltica was growing without ciliates (time $=4 \mathrm{~h}, \mathrm{n}=3$ )

\begin{tabular}{|ccc|}
\hline $\begin{array}{c}\text { Algal suspension } \\
\left(10^{3} \text { cells }^{-1}\right)\end{array}$ & $\begin{array}{c}\text { Ingestion rate } \\
{\left.\text { (cells ciliate } \mathrm{h}^{-1}\right)}^{-1}\end{array}$ \\
\hline $\mathbf{R}$ & $\mathbf{P}$ & \\
10 & 0 & $35 \pm 7$ \\
10 & 2 & $29 \pm 6$ \\
10 & 4 & $27 \pm 6$ \\
10 & 8 & $14 \pm 2$ \\
10 & 16 & $-18 \pm 2$ \\
10 & 32 & $-24 \pm 6$ \\
\hline
\end{tabular}


P. parvum was, prior to the experiment, grown as batch cultures under 3 different nutrient concentrations; $14.5 \mu \mathrm{M} \mathrm{NO}_{3}{ }^{-}: 3.6 \mu \mathrm{M} \mathrm{PO}_{4}{ }^{3-}$ (nitrogen-deficient, $\mathrm{N}: \mathrm{P}=$

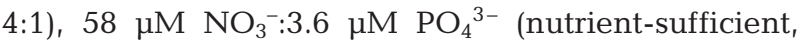
$\mathrm{N}: \mathrm{P}=16: 1$ ) and $58 \mu \mathrm{M} \mathrm{NO}_{3}{ }^{-}: 0.9 \mu \mathrm{M} \mathrm{PO}_{4}{ }^{3-}$ (phosphorusdeficient, $\mathrm{N}: \mathrm{P}=64: 1)$. $R$. cf. baltica was grown as batch cultures under a nutrient concentration of $58 \mu \mathrm{M} \mathrm{NO}_{3}{ }^{-}$: 3.6 $\mathrm{MM} \mathrm{PO}_{4}{ }^{3-}$ (nutrient-sufficient, $\mathrm{N}: \mathrm{P}=16: 1$ ). Cells of $P$. parvum were harvested in mid-exponential phase (nutrient-sufficient cultures) or late exponential/stationary growth phase ( $\mathrm{N}$ - or P-limited cultures), while $R$. cf. baltica were harvested at mid-exponential phase. The concentrations of $\mathrm{NO}_{3}{ }^{-}, \mathrm{PO}_{4}{ }^{3-}$ and $\mathrm{NH}_{4}{ }^{+}$in the cultures were analysed according to Valderama (1995). To attain different experimental concentrations of the 2 algae, the cultures were diluted with autoclaved seawater (nutrient concentrations: $0.1 \mu \mathrm{M} \mathrm{PO}_{4}{ }^{3-}$ and $1.2 \mu \mathrm{M} \mathrm{NO}_{3}{ }^{-}$). Each algal concentration consisted of 12 replicate wells initially containing 4 ciliates and $2 \mathrm{ml}$ of algal suspension. This means that initially we had a total of 48 ciliates (the sum of the 12 replicate wells) for each of the treatments. The growth response of the ciliates were measured after 12, 24, 36 and $48 \mathrm{~h}$ by sampling 3 out of 12 replicate wells at each time which were fixed with Lugol's solution and counted under a microscope. The underlying assumption was that the measured ciliate density of the wells taken at each point in time was representative for all 12 replicate wells. Thus, our results in the figures are based on the multiplication of the the ciliate/algal cell numbers in each of the 3 sampled wells, by 12. The same experimental procedure was used for $P$. parvum cultures grown at different nutrient conditions. Experiments were carried out at constant low light intensity $\left(15 \mu \mathrm{mol} \mathrm{m}{ }^{-2} \mathrm{~s}^{-1}\right)$ to ensure minimal growth of the prey during the experiments.

Toxicity test: survival of Artemia salina nauplii. Prior to the growth experiment, the toxicity of Prymnesium parvum cultures grown under different nutrient conditions was tested using an Artemia-assay. The reason to use this test is because, although some of the toxins are identified (see Igarashi et al. 1998, Sasaki et al. 2001), a chemical method will only be possible after all the toxins have been identified. Eggs of $A$. salina (Mackay Marine Brine Shrimp) were hatched according to Vanhaecke et al. (1981) using filtered $(90 \mathrm{~mm}$ membrane filter [Gelman Science] mesh size $0.45 \mu \mathrm{m}$ ) autoclaved seawater with a salinity of $7 \%$ and $\mathrm{pH} 8.0$. The eggs were kept under constant aeration at a temperature of $25^{\circ} \mathrm{C}$ with PAR of $100 \mu \mathrm{mol} \mathrm{m} \mathrm{m}^{-2} \mathrm{~s}^{-1}$ under continuous light. After 18 to $24 \mathrm{~h}$, hatched Artemia nauplii (Developmental Stage 1) were transferred to fresh seawater and kept for an additional $24 \mathrm{~h}$. The transfer was made in order to be sure that all the nauplii used for the test had reached the same develop- mental stages. The nauplii were kept under the same conditions as the eggs. The tolerance of $A$. salina to the different cultures of $P$. parvum was examined on nauplii $48 \mathrm{~h}$ after egg hatching began (Developmental Stages 2 and 3).

The different cultures of Prymnesium parvum were diluted with filtered, autoclaved seawater $(7 \%)$ to give a dilution series of $100,50,30,10,5$, and $2.5 \%$. Filtered autoclaved seawater was used as a control. Ten $\mathrm{ml}$ of each dilution was added to a $10 \mathrm{ml}$ well (Falcon multiwell, 6-wells), 10 nauplii were transferred to each well, and 3 replicates were used for each algal concentration. After $24 \mathrm{~h}$ in darkness at a temperature of $25^{\circ} \mathrm{C}$, the mortality of nauplii at each concentration was examined. Dead nauplii were observed under a microscope and the nauplii were considered dead if no movement of the appendages was observed within $10 \mathrm{~s}$ (Vanhaecke et al. 1981). The mortality was transformed into probit units according to Hewlett \& Plackett (1979) and plotted against log-transformed cell concentration. From the regression line, the $50 \%$ mortality ( $24 \mathrm{~h} ; \mathrm{LC}_{50}$ ) was calculated.

\section{RESULTS}

\section{Ingestion rate}

Maximum ingestion rate of Euplotes affinis was reached at a prey concentration of approximately $6 \times$ $10^{3}$ Rhodomonas cf. baltica cells $\mathrm{ml}^{-1}$ (Fig. 1). When Prymnesium parvum was offered as the only food source, grazing was not observed at any concentration, resulting in negative ingestion rates. Experiments in which $E$. affinis was offered a mixed food source con-

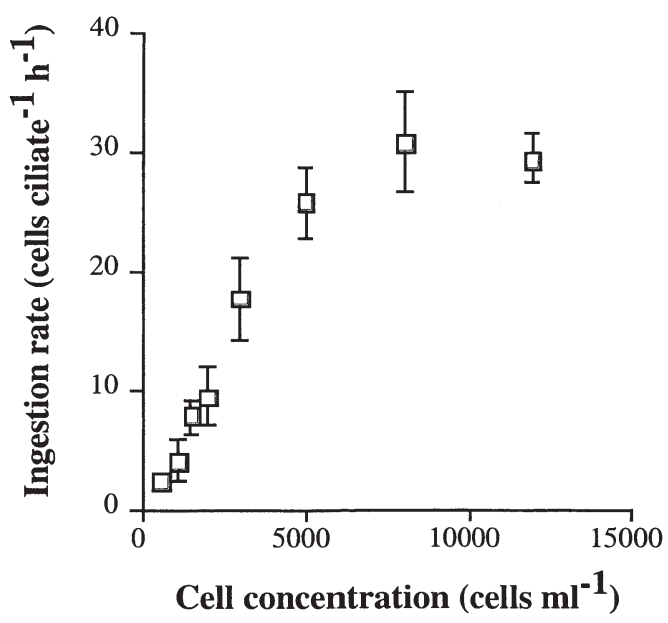

Fig. 1. Ingestion rates for Euplotes affinis fed increasing concentrations of Rhodomonas cf. baltica (time $=4 \mathrm{~h}, \mathrm{n}=3$ ) 
sisting of a fixed cell concentration of $R$. cf. baltica $(10 \times$ $10^{3}$ cells ml ${ }^{-1}$ ) and various concentrations of $P$. parvum showed that the feeding on Rhodomonas cells decreased as the concentration of $P$. parvum increased (Table $1, t$-test). Thus, $P$. parvum were not only rejected as a food source, but their presence also inhibited feeding on normally edible phytoplankton cells (Table 1).

\section{Growth of Euplotes affinis}

When Euplotes affinis was exposed to a fixed concentration of Rhodomonas cf. baltica and various concentrations of Prymnesium parvum cells grown under nutrient sufficient conditions, the growth of $E$. affinis was unaffected at $P$. parvum concentrations below $8 \times$ $10^{3}$ cells ml ${ }^{-1}$ (Fig. 2). At a concentration of $8 \times 10^{3}$ $P$. parvum cells $\mathrm{ml}^{-1}$, the cell numbers of $E$. affinis increased during the first $36 \mathrm{~h}$ and then declined. At P. sparvum concentrations above $8 \times 10^{3} \mathrm{cells} \mathrm{ml}^{-1}$ the ciliates were unable to sustain growth and the number of ciliates decreased (Fig. 2).

When the ciliates were exposed to a fixed concentration of Rhodomonas cf. baltica and various concentrations of Prymnesium parvum cells grown under N- or P-deficient conditions, the ciliates showed a different growth response. The ciliates were growing well at $2 \times$ $10^{3}$ P. parvum cells $\mathrm{ml}^{-1}$ (Fig. 2), but at concentrations exceeding $2 \times 10^{3}$ cells ml ${ }^{-1}$ Euplotes affinis was not able to grow and survival decreased as the concentration of P. parvum increased (Fig. 2). E. affinis exposed to $P$. parvum cells grown under nutrient-deficient conditions ( $\mathrm{N}$ or $\mathrm{P}$ ) showed a higher mortality than cells exposed to nutrient-sufficient P. parvum cells (Fig. 3), suggesting that nutrient limitation stimulated the toxin production in P. parvum.

\section{Survival of Artemia salina nauplii}

The tolerance of Artemia salina nauplii to different Prymnesium parvum cultures was dependent on the physiological status of the $P$. parvum cells. The $\mathrm{LC}_{50}$ value of cultures grown under nutrient-sufficient conditions was calculated to be $26.5 \times 10^{3}$ cells $\mathrm{ml}^{-1}$ (Fig. 4). Artemia salina was less tolerant to P. parvum cultures grown under $\mathrm{N}$ - or P-deficient conditions, resulting in $\mathrm{LC}_{50}$ values of $3.0 \times 10^{3}$ and $2.0 \times 10^{3}$ cells $\mathrm{ml}^{-1}$, respectively (Fig. 4).

\section{DISCUSSION}

In the present study, we demonstrate an inhibitory feeding response of the haptophyte algae Prymnesium
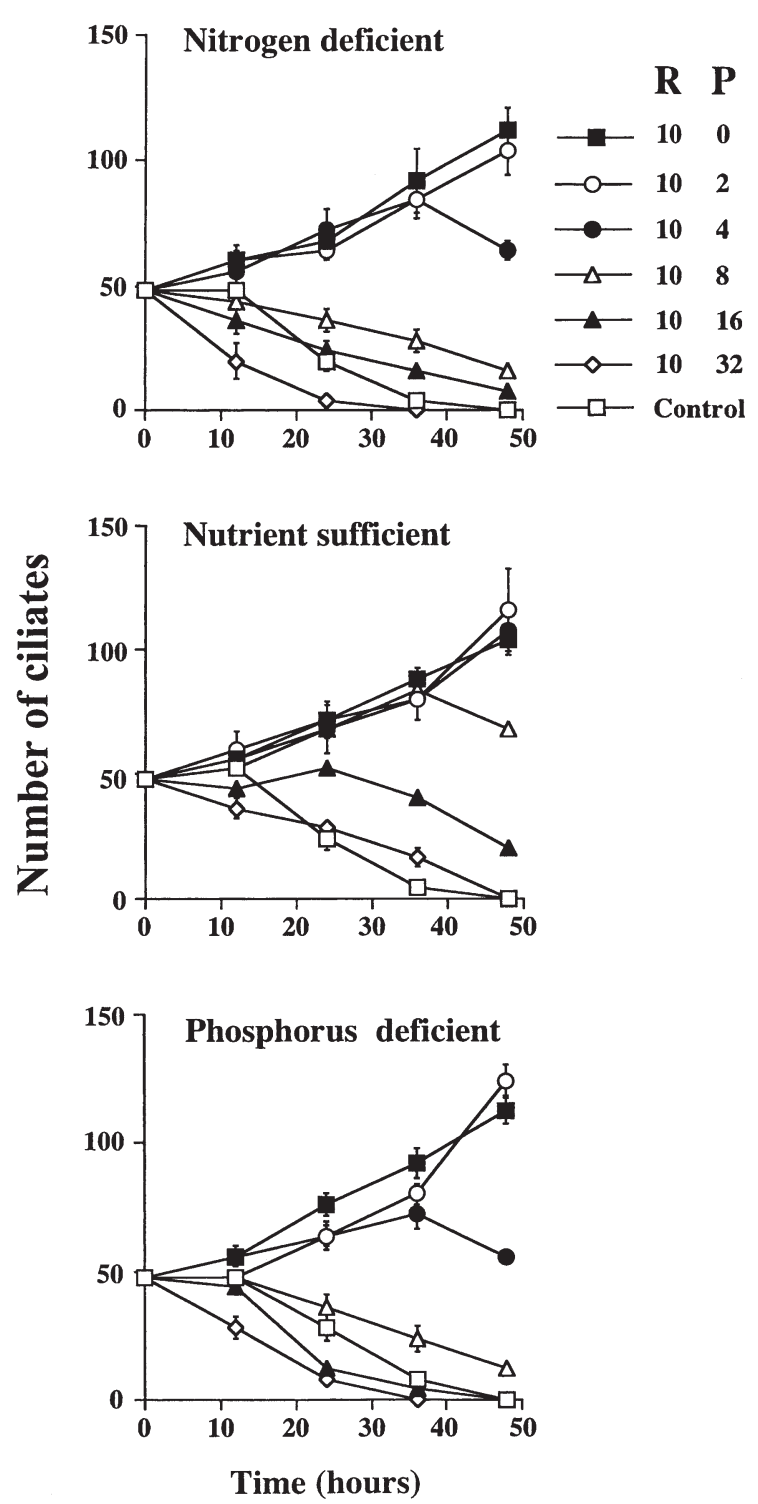

Fig. 2. Growth respones of Euplotes affinis when fed monocultures of Rhodomonas cf. baltica (R) or mixtures of $R$. cf. baltica and various concentrations of Prymnesium parvum (P) cells grown under nitrogen-deficient, nutrient-sufficient or phosphorus-deficient conditions. Pure algal medium was used as starvation control

parvum on the ciliate Euplotes affinis. The ciliate was growing well when fed monocultures of the Rhodomonas cf. baltica, whereas it avoided grazing on monocultures of $P$. parvum, irrespective of the algal concentration. Furthermore, we found that increasing abundances of $P$. parvum increased the mortality of the ciliate, even if supplied as a mixture together with high concentrations of $R$. cf. baltica as an alternative prey. This suggests that toxic substances excreted into the medium were responsible for the observed mortality. 

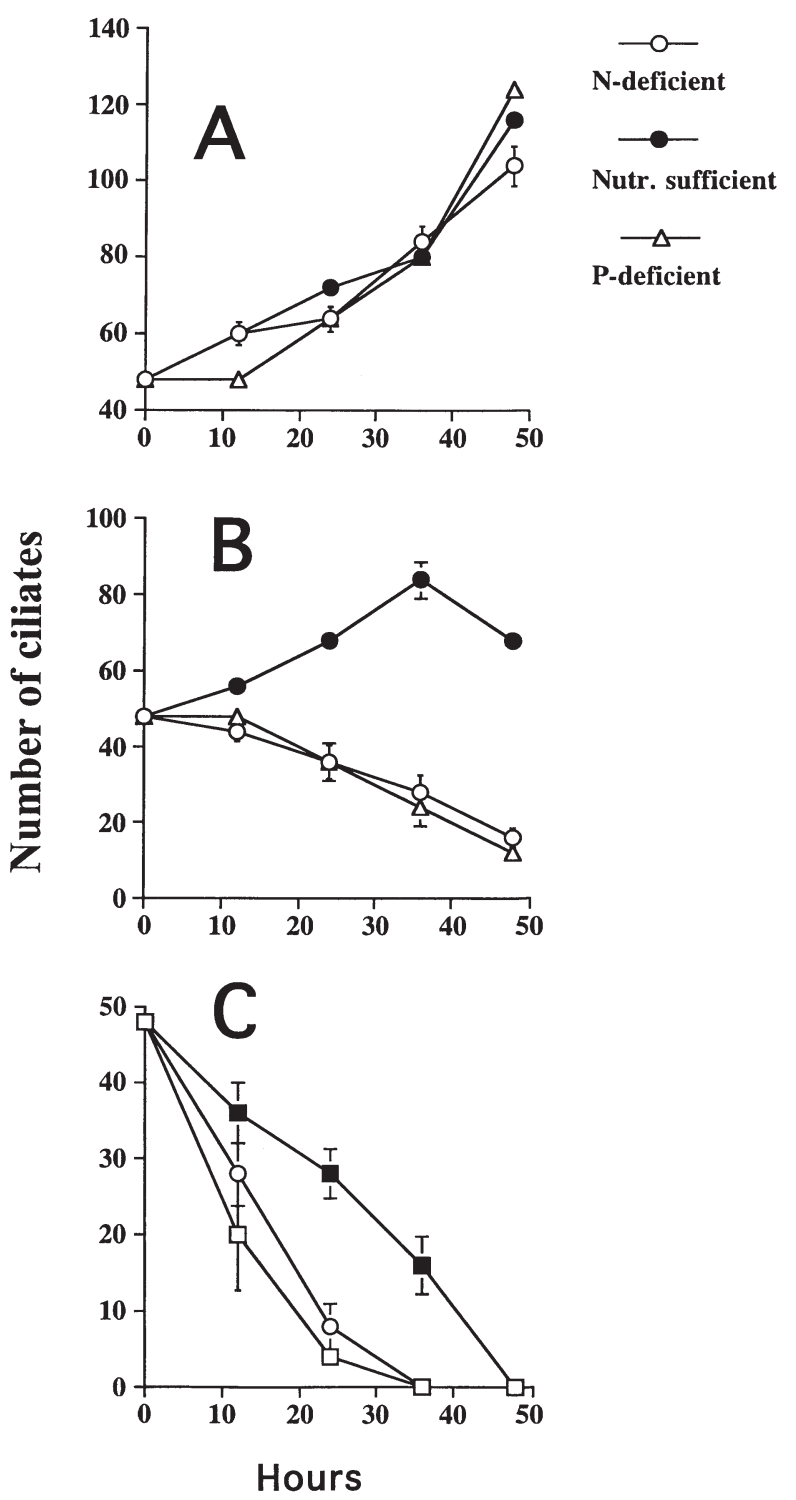

Fig. 3. Euplotes affinis related to differences in nutrient conditions. Growth responses of $E$. affinis exposed to mixtures of Rhodomonas cf. baltica. and Prymnesium parvum as follows: (A) 10 000:2000, (B) 10 000:8000, and (C) 10 000:32 000. P. parvum cells were grown under $\mathrm{N}$ - and $\mathrm{P}$-deficient and under nutrient-sufficient conditions. $R$. cf. baltica cells were grown solely under nutrient-sufficient conditions

Granéli \& Johansson (2003) have shown that addition of $P$. parvum filtrates from cultures which had grown under $\mathrm{N}$ - or P-deficient conditions contained toxic substances able to kill several phytoplankton species. There was a clear difference in the degree of growth inhibition of the ciliate, whether nutrient-limited or nutrient-sufficient $P$. parvum cultures were offered as prey, suggesting that the survival of the ciliate in the presence of toxic $P$. parvum cells was strongly influenced by the physiological status of the $P$. parvum cells. It is well known that $P$. parvum under certain conditions produces highly potent toxins that are released to the water (Shilo 1967). These toxins have a broad spectrum of different biological effects, including ichthyotoxic, neurotoxic, cytotoxic, hepatotoxic and hemolytic activity towards a range of marine organisms (Valkanov 1964, Shilo 1971). Several studies have shown that the toxic effect of $P$. parvum is enhanced under nutrient stress (Shilo 1971, Johansson \& Granéli 1999), and toxic substances released to the medium have been reported to suppress growth of other algae (Granéli \& Johansson in press) and cause fish mortality under nutrientlimiting conditions (Aure \& Rey 1992). Although the toxicity of cell-free filtrates of $P$. parvum was not tested in the present study, it seems likely that a similar mechanism was responsible for the negative effect of $P$. parvum cells on the E. affinis cells.

Several phytoplankton species have been reported to release toxic substances with negative effects on both ciliates and copepods. Huntley et al. (1986), for instance, reported that toxic substances released by the dinoflagellate Protoceratium reticulatum induced mortality of the copepod Calanus pacificus. Similarly, certain dinoflagellate species have been found to secrete substances with a negative influence on the ciliate Favella ehrenbergii (Hansen 1989, 1995, Hansen et al. 1992). Among haptophytes, Carlsson et al. (1990) showed that Chrysochromulina polylepis releases toxic substances that are lethal to the ciliate F. ehrenbergi. In laboratory experiments, both Prymnesium patelliferum and C. polylepis strongly affect copepod feeding and reproduction (Nielsen et al. 1990, Nejstgaard et al. 1995, Nejstgaard \& Solberg 1996). These results support the conclusion that toxin production in phytoplankton can be a mechanism to escape grazing. In spite of several studies of toxic interactions between phytoplankton and potential grazers, the mechanism has rarely been related to the nutrient condition of the ambient water. Carlsson et al. (1990) demonstrated that cells of the haptophyte $C$. polylepis were more lethal to the ciliate $F$. ehrenbergii when grown under P-limited conditions compared to cells grown under nutrient-sufficient conditions. Further, Hansen (1989) and Hansen et al. (1992) found that the toxic dinoflagellates Alexandrium tamarense and A. ostenfeldii produce substances that are lethal to the ciliate $F$. ehrenbergii when released to the medium. The toxicity of the medium was dependent on the growth phase, with the highest toxicity during the stationary phase. This suggests a close relationship between growth limitation and excretion of toxic substances by certain phytoplankton.

Negative effects on predators due to production of toxic substances would be valuable for any phyto- 

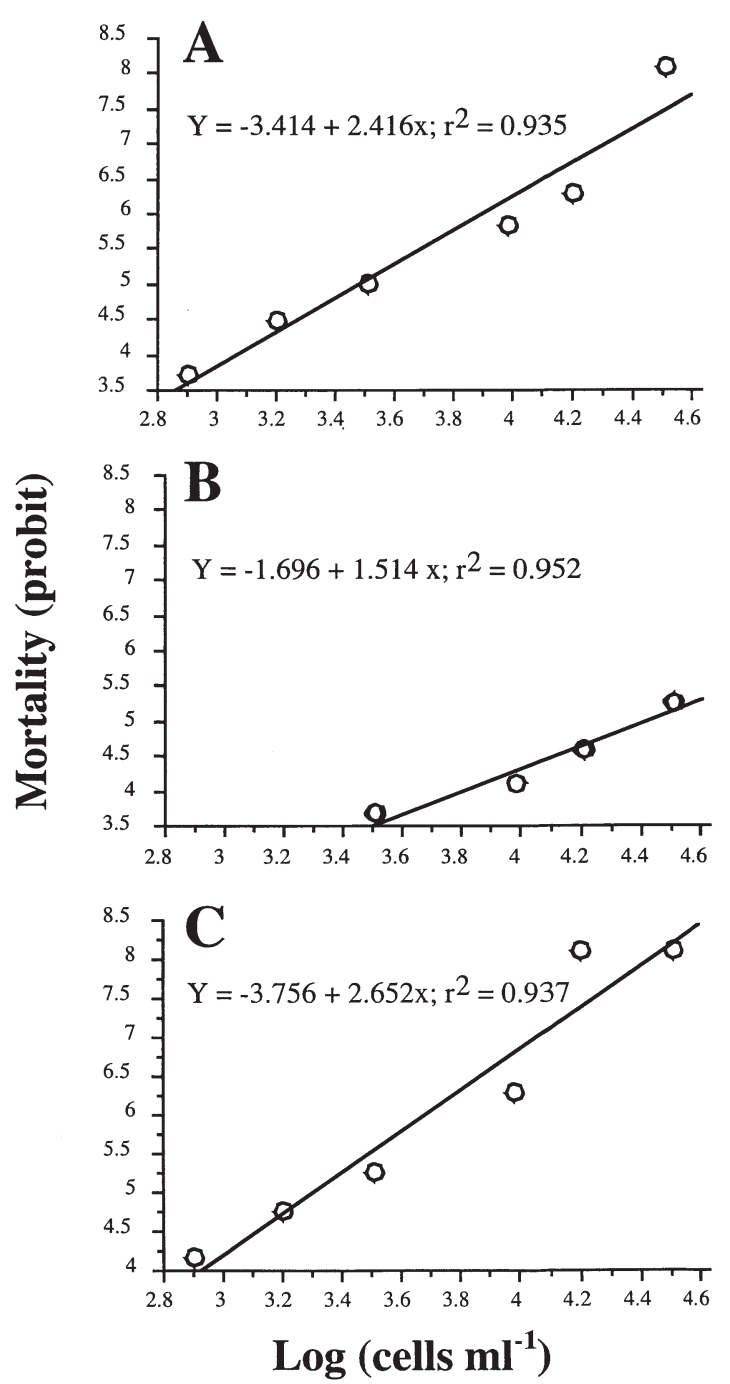

Fig. 4. Dose-response relationship of cultures of Prymnesium parvum on nauplii of Artemia salina. Cultures of P. parvum were grown under (A) nitrogen-deficient, (B) nutrientsufficient or (C) phosphorus-deficient conditions

plankton species. The underlying assumption is that blooms of these algal species can develop without regulation due to zooplankton grazing, which have been considered an important loss factor during bloom formation of phytoplankton (Watras et al. 1985). Several studies have reported that blooms of toxic phytoplankton species may initiate and develop in natural waters as a result of reduction or absence of grazers due to toxic interactions. For instance, the large bloom of Chrysochromulina polylepis in 1988 in Scandinavian waters has been suggested to develop partly due to reduced grazing (Dahl et al. 1989, Maestrini \& Granéli 1991).

Field observations have shown that Prymnesium parvum are capable of forming more or less monospe- cific blooms, which may persist in the water for several weeks (Lindholm et al. 1999). This suggests a mechanism to inhibit or avoid zooplankton grazers. However, to our knowledge, there is no information on the importance of zooplankton grazing for the development of P. parvum blooms in nature. Nevertheless, the present study implies that zooplanktonic grazers, at least in the case of Euplotes affinis, avoid grazing on monocultures of $P$. parvum. This is supported by Valkanov (1964) and Lindholm et al. (1999), which reported a substantial reduction in the abundance of zooplankton during natural blooms that were heavily dominated by P. parvum. At the beginning of a bloom, $P$. parvum will occur together with other phytoplankton species. The present study showed that E. affinis grew well at low concentrations of $P$. parvum (2 to $4 \times$ $10^{3}$ cells $\mathrm{ml}^{-1}$ ) if an alternative prey was present at high concentrations. Similar relationships have been reported between ciliates and other toxic phytoplankton species (Verity \& Stoecker 1982, Hansen 1995). That is, ciliates can thrive among algae producing potent exotoxins, as long as the density of these algae is low and the algae do not dominate the phytoplankton assemblage.

The mechanism responsible for the lethal effect on Euplotes affinis cells is not clear. On several occasions in the present study we observed that in some of the wells ciliates were completely absent, suggesting cell lysis. Hansen (1989) reported that the dinoflagellate Alexandrium tamarense excretes toxic substances to the medium that acts on the cell membrane of ciliates, making them swell and subsequently lyse. The toxins produced by Prymnesium cells are also known to act on cell membranes and disrupt the ability of selective permeability (Shilo 1967), which Meldahl et al. (1996) thought was probably due to an influx of $\mathrm{Ca}^{2}$. However, recent studies by Igarashi et al. (1998), have shown that the haemolytic activity of prymnesins are not affected by $\mathrm{Ca}^{2}$ but by the origen of the blood cell being tested. Several studies have shown that Prymnesium toxins damage cell membranes and exert lytic effects on various cell types including blood cells, human liver cells and amnion cells (Shilo \& Rosenberger 1960, Meldahl \& Fonnum 1993, Johansson \& Granéli 1999, Granéli \& Johansson 2003). Although we did not see the ciliate cells lyse, it is possible that $P$. parvum toxins have a similar mode of action on ciliates.

In conclusion, our results show that Prymnesium parvum were not grazed by the ciliate Euplotes affinis. $P$. parvum had a negative effect on the survival of the ciliate, even if supplied as a mixture together with a non-toxic prey. This implies that $P$. parvum produced substances that are lethal to the ciliate when released to the medium. The toxic effect of $P$. parvum was 
dependent on the physiological status of the algal cells, with the highest toxicity in nutrient-stressed cultures. This was clearly demonstrated by a higher mortality when E. affinis were incubated with $P$. parvum cells grown under nutrient-limited ( $\mathrm{N}$ or $\mathrm{P}$ ) conditions, compared to when incubated with nutrient-sufficient cells. From these results we suggest that toxin production in $P$. parvum may be a chemical defence against grazers, and that toxic interactions between $P$. parvum and potential grazers may be an important mechanism in the development and maintenance of blooms of this species in nature.

Acknowledgements. This work was supported by the Swedish Environmental Protection Agency, the Swedish Council for Forestry and Agricultural Research, the C. Trygger Foundation, Stockholm, The Royal Physiographic Society, Lund, Sweden, the Crafoord Foundation, Lund, and by the European Commission (Research Directorate General-Environment Programme-Marine Ecosystems) through the FATE project (contract holder E.G., EC grant EVK3-2001-00050).

\section{LITERATURE CITED}

Aure J, Rey F (1992) Oceanographic conditions in the Sandfjord system, western Norway, after a bloom of the toxic prymnesiophyte Prymnesium parvum Carter in August 1990. Sarsia 76:247-254

Carlsson P, Granéli E, Olsson P (1990) Grazer elimination through poisoning: one of the mechanisms behind Chrysochromulina polylepis blooms. In: Granéli E, Sundström B, Edler L, Anderson DM (eds) Toxic marine phytoplankton. Elsevier, New York, p 116-122

Carlsson P, Granéli E, Finenko G, Maestrini SY (1995) Copepod grazing on a phytoplankton community containing the toxic dinoflagellate Dinophysis acuminata. J Plankton Res 17:1925-1938

Dahl E, Lindahl O, Paasche E, Throndsen J (1989) The Chrysochromulina polylepis bloom in Scandinavian waters during spring 1988. In: Cosper EM, Bricelj VM, Carpenter EJ (eds) Coastal and estuarine studies 35: novel phytoplankton blooms. Springer-Verlag, Berlin, p 383-405

De Mott WR, Moxter F (1991) Foraging on cyanobacteria by copepods: responses to chemical defenses and resource abundance. Ecology 72:1820-1834

De Mott WR, Zhang QX, Carmichael WW (1991) Effects of toxic cyanobacteria and purified toxins on the survival and feeding of a copepod and three species of Daphnia. Limnol Oceanogr 36:1346-1357

Edvardsen B, Paasche E (1998) Bloom dynamics and physiology of Prymnesium and Chrysochromulina. In: Anderson DM, Cembella AD, Hallegraeff GM (eds) The physiological ecology of harmful algal blooms. Springer-Verlag, Heidelberg, p 193-208

Frost BW (1972) Effects of size and concentration of food particles on the feeding behaviour of the marine planktonic copepod Calanus pacificus. Limnol Oceanogr 17: 805-815

Granéli E, Johansson N (2003) Increase in the production of allelopathic substances by Prymnesium parvum cells grown under $\mathrm{N}$ or $\mathrm{P}$ deficient conditions. Harmful Algae 42:1-11
Guillard RR, Ryther JH (1962) Studies of marine planctonic diatoms. I. Cyclotella nana Hustedt and Detonula convervacea (Cleve). Gran Can J Microbiol 8:229-239

Hansen PJ (1989) The red tide dinoflagellate Alexandrium tamarense: effects on behaviour and growth of a tintinnid ciliate. Mar Ecol Prog Ser 53:105-116

Hansen PJ (1995) Growth and grazing response of a ciliate feeding on the red tide dinoflagellate Gyrodinium aureolum in monoculture and in mixture with a non-toxic alga. Mar Ecol Prog Ser 121:65-72

Hansen PJ, Cembella AD, Moestrup Ø (1992) The marine dinoflagellate Alexandrium ostenfeldii: paralytic shellfish toxin concentration, composition, and toxicity to a tintinnid ciliate. J Phycol 28:597-603

Hewlett PS, Plackett RL (1979) An introduction to the interpretation of quantal responses in biology. Edward Arnold, London, p 11-19

Huntley M, Sykes P, Marin V (1986) Chemically-mediated rejection of dinoflagellate prey by the copepods Calanus pacificus and Paracalanus parvus: mechanism, occurrence and significance. Mar Ecol Prog Ser 28:105-120

Igarashi T, Aritake S, Yasumoto T (1998) Biological activities of prymnesin-2 isolated from a red tide alga Prymnesium parvum. Natural Toxins 6:35-41

Ives JD (1985) The relationship between Gonyaulax tamarensis cell toxin levels and copepod ingestion rates. In: Anderson DM, White AW, Baden DG (eds) Toxic dinoflagellates. Elsevier, North Holland, New York, p 413-418

Ives JD (1987) Possible mechanisms underlying copepod grazing responses to levels of toxicity in red tide dinoflagellates. J Exp Mar Biol Ecol 112:131-145

Johansson M (2002) Ciliates in marine food webs - behaviours structuring plankton communities. PhD thesis, Stockholm University

Johansson N, Granéli E (1999) Influence of different nutrient conditions on cell density, chemical composition and toxicity of Prymnesium parvum (Haptophyta) in semicontinuous cultures. J Exp Mar Biol Ecol 239:243-258

Kamiyama T, Arima S (1997) Lethal effect of the dinoflagellate Heterocapsa circularisquama upon the tintinnid ciliate Favella taraikaensis. Mar Ecol Prog Ser 160:27-33

Lindholm T, Öhman P, Kurki Helasmo K, Kincaid B, Meriluoto $\mathrm{J}$ (1999) Toxic algae and fish mortality in a brackish-water lake in Åland, SW Finland. Hydrobiologia 397:109-120

Maestrini SY, Granéli E (1991) Environmental conditions and ecophysiological mechanisms which led to the 1988 Chrysochromulina polylepis bloom: an hypothesis. Oceanol Acta 14:397-413

Meldahl AS, Fonnum F (1993) Effect of toxin of Prymnesium patelliferum on neurotransmitter transport mechanisms: development of a sensitive method. J Toxicol Environ Health 38:57-67

Meldahl AS, Edvardsen B, Fonnum F (1994) Toxicity of four potentially ichtyotoxic marine phytoflagellates determined by four different test methods. J Toxicol Environ Health 42:289-301

Meldahl AS, Aas P, Fonnum F (1996) Extract of the marine alga Prymnesium patelliferum induces release of acetylcholine from cholinergic nerves in the rat bronchial smooth muscle. Acta Physiol Scand 156:99-107

Moestrup Ø (1994) Economic aspects: blooms, nuisance species, and toxins. In: Green JC, Leadbeater BSC (eds) The haptophyte algae. Systematics Association Special, Vol 51. Clarendon Press, Oxford, p 265-285

Nejstgaard JC, Solberg PT (1996) Repression of copepod feeding and fecundity by the toxic haptophyte Prymnesium patelliferum. Sarsia 81:339-344 
Nejstgaard JC, Båmstedt U, Bagøien E (1995) Algal constraints on copepod grazing. Growth state, toxicity, cell size, and season as regulating factors. ICES J Mar Sci 52: 347-357

Nielsen TG, Kiørboe T, Bjørnsen PK (1990) Effects of a Chrysochromulina polylepis subsurface bloom on the planktonic community. Mar Ecol Prog Ser 62:21-35

Sasaki M, Shida T, Tachibana K (2001) Synthesis and stereochemical confirmation of the HI/JK ring system of prymnesins, potent hemolytic and ichthyotoxic glycoside toxins isolated from the red tide alga. Tetrahedron Lett 42: 5725-5728

Schöne HK, Schöne A (1982) A weakly enriched sea-water medium for ecological studies on marine plankton algae, some examples of its application. Bot Mar 25:117-122

Shilo M (1967) Formation and mode of action of algal toxins. Bacteriol Rev 31:180-193

Shilo M (1971) Toxins of Chrysophycae. In: Kadis S, Ciegler A, Ajl SJ (eds) Microbial toxins. Algal and fungal toxins 7. Academic Press, New York, p 67-103

Shilo M, Rosenberger RF (1960) Studies on the toxic principles formed by the chrysomonad Prymnesium parvum Carter. Ann NY Acad Sci 90:866-876

Strodtmann S (1898) Über die vermeintliche Schädlichkeit der Wasserblüte. Forschungsber Biol Stn Plön 6:206-212

Sykes PF, Huntley ME (1987) Acute physiological reactions of

Editorial responsibility: Otto Kinne (Editor),

Oldendorf/Luhe, Germany
Calanus pacificus to selected dinoflagellates: direct observations. Mar Biol 94:19-24

Thomsen HA (1992) Plankton in the inland Danish waters. Marine Research from the Environmental Department, No. 11 Danish Environmental Department, Copenhagen

Uye S (1986) Impact of a copepod grazing on the red-tide flagellate Chatonella antiqua. Mar Biol 92:35-43

Valderama JC (1995) Methods of nutrient analysis. In: Hallegraeff GM, Anderson DM, Cembella AI (eds) Manual of harmful marine microalgae. IOC, Manuals and Guides No 33. UNESCO, Paris, p 251-268

Valkanov A (1964) Untersuchungen über Prymnesium parvum Carter und seine toxische Einwirkung auf die Wasserorganismen. Kiel Meeresforsch 20:65-81

Vanhaecke P, Persoone G, Claus C, Sorgeloos P (1981) Proposal for a short-term toxicity test with Artemia nauplii. Ecotoxicol Environ Saf 5:382-387

Verity PG, Stoecker D (1982) Effects of Olisthodiscus luteus on the growth and abundance of tintinnids. Mar Biol 72: 79-87

Watras CJ, Garcon VC, Olson RJ, Chisholm SW, Anderson DM (1985) The effect of zooplankton grazing on estuarine blooms of the toxic dinoflagellate Gonyaulax tamarensis. J Plankton Res 7:891-908

Yariv J, Hestrin S (1961) Toxicity of the extracellular phase of Prymnesium parvum cultures. J Gen Microbiol 24:165

Submitted: April 18, 2000; Accepted: February 28, 2003

Proofs received from author(s): May 2, 2003 